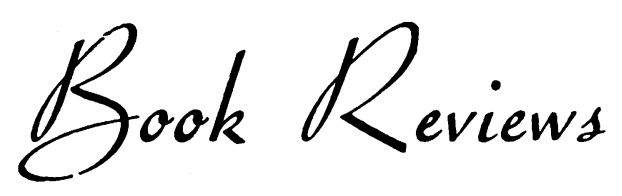

\section{FOOD WITH LOW PHENYLALANINE CONTENT FOR DIETARY TREATMENT OF PHENYLKETONURIA}

A food for the dietary treatment of phenylketonuria is now available from Trufood Ltd. Based on the diet published in the British Medical Fournal, January 8, 1955, 'Treatment of Phenylketonuria with a Diet Low in Phenylalanine' (Woolf, Griffiths and Moncrieff), this food contains not more than $8.5 \mathrm{mg}$. per $100 \mathrm{~g}$.

It was produced to obviate the complicated and tedios preparation previously necessary with this diet, and provides approximately 540 calories per roo g. with approximately $3 \mathrm{I} \mathrm{g}$. fat, $17.5 \mathrm{~g}$. protein and $48 \mathrm{~g}$. carbohydrate. No provision is made in the food for vitamins $A, D$ and $C$ which have to be given separately.

The food is in the form of a powder which, when whisked with boiling water, produces a smooth mixture. The proportions of powder to water will, of course, vary according to the dietetic requirements of the patient.

This compound will be supplied under the trade name Minafen. To meet the urgent need for the simplification of the preparation of the diet in the treatment of phenylketonuria, Minafen is being made available in temporary $1 \mathrm{lb}$. and $3 \mathrm{lb}$. packs (approximately $450 \mathrm{~g}$. and $\mathrm{I}, 360 \mathrm{~g}$. respectively). Enquiries should be made to the Trufood London office, I I 3 Newington Causeway, London, S.E.I. Telephone: HOP 5964.

\section{CIBA FOUNDATION SYMPOSIUM ON THE NATURE OF VIRUSES}

Edited by G. E. W. Wolstenholme, O.B.E., M.A., M.B., B.Ch., and Elaine C. P. Millar, A.M.W.C., A.R.I.C. Pp. xii +292 , illustrated. London: J. \& A. Churchill Ltd. I957. $42 \mathrm{~s}$.

Once more the Ciba Foundation has placed the profession in its debt by collecting together a number of the leading figures in a specialized field to present their views and to discuss them freely. The informality in the presentation of the discussion brings out the points of interest and importance in a way that no monograph or textbook can do, and the reader is left with a far better idea of the limits of the assured knowledge and the range of speculation in this field. For the non-specialist reader (the specialist will already have obtained a copy) it is an advantage to take this book together with the earlier symposium on virus multiplication published by the Society for General Microbiology.

Particular prominence in the present saries of contributions is given to X-ray defraction studies, chemical analysis of virus, virus multiplication and its relationship to cells and the morphological effects on them.

\section{CLEFT LIP AND PALATE}

By W. G. Holdsworth, F.R.C.S. Pp. $x i+r 87$. with 146 illustrations. Second Edition. London: William Heiremann Ltd. I $957.42 \mathrm{~s}$.

This excellent monograph in its second edition has been enlarged by the addition of a chapter on embryology by Professor Harrison and one on orthodontic treatment by M. A. Kettle.

No space is wasted in this book, which is packed with information concerning numerous operative methods. It may truly be described as a guide and companion for all interested in this surgical field.

\section{MEDICINE AND THE NAVY, 1200-1900 Vol. I: 1200-1649}

By Surgeon-Commander J. J. KEEvIL, D.S.O., M.A., M.D., R.N. (Retd.). Pp. viii +255 , with I5 illustrations. Edinburgh: E. \& S. Livingstone Ltd. I 957.405.

Few who only know what old sailors call the ' New Navy' would believe that a big book could be written on medicine in its naval context. In the first volume of his new work on this subject Surgeon-Commander Keevil has shown how much there is to be recalled in our great sea-past that is very relevant to the doctor's activities in those days, and he takes us from a Norman craft-guild in the twelfth century, through medieval and Tudor times to the more regular activities of the BarberSurgeons' Company in the days of Charles I. For his industry in thus covering the many-sided matter of his subject the author must be commended, and though its interest to the general reader may not be as strong as to those who have their hearts in ships, no doctor of today will read without a shudder of the fearful seagoing hardships of his forebears and their sturdy charges, or will fail to give thanks for the passing of those voyages of terror. We must look forward to the rest of the story that is yet to come.

H.H.G.E. 